\title{
Synthesis, structure and properties of $V(V)$ monooxido complex with ONO tridentate Schiff base
}

\author{
Anna Jurowska, Janusz Szklarzewicz*, Maciej Hodorowicz, Ryszard Gryboś \\ Jagiellonian University, Faculty of Chemistry, Gronostajowa 2, 30-387 Kraków, Poland
}

\section{Article history:}

Received 7 December 2018

Received in revised form

22 February 2019

Accepted 14 March 2019

Available online 14 March 2019

\begin{abstract}
The oxidovanadium(V) Schiff base complex of formula [VO(L) $(\mathrm{EtO})(\mathrm{EtOH})]$ (where $\mathrm{H}_{2} \mathrm{~L}=$ Schiff base ligand derived from 5-methoxysalicylaldehyde and phenylacetic hydrazide) was synthesized and described. Complex crystalizes in triclinic $P_{-1}$ space group. Octahedral geometry of the vanadium $(\mathrm{V})$ centre is filed with oxido, $\mathrm{ONO} \mathrm{L}^{2-}$ ligand and two solvent molecules both in ethoxo and as neutral ethanol form. The complex is neutral, with 5- and 6-memebered ring formed by ONO ligand coordinated in octahedral plane with oxido and EtOH ligands in vertical positions. Two isomers are present in the unit cell, with different position of 5-membered ring versus vertical plane. The elemental analysis, magnetic susceptibility, thermogravimetry and spectroscopy (IR, UV-Vis) measurements were measured and are discussed. The cyclic voltammetry measurements show irreversible processes for vanadium(IV/V) redox system. Thermal stability both in a solid state (TG and SDTA measurements) as well as in solutions (at $\mathrm{pH} 7.0$ and 2.0, studied by UV-Vis spectroscopy) is discussed.
\end{abstract}

Keywords: vanadium, complex, Schiff base, structure, 5-methoxysalicylaldehyde, phenylacetic hydrazide

\section{Introduction}

Vanadium(V) forms stereochemically flexible complexes, where the thermodynamically acceptable coordination geometries range from tetrahedral and octahedral to trigonal pyramidal and pentagonal bipyramidal [1]. The vanadium-containing compounds are particularly interesting due to their use as insulin-mimetic agents and there are three general classes of such compounds: 1) inorganic vanadium anionic or cationic salts $\left(\left[\mathrm{VO}_{4}\right]^{3-}\right.$ or $\left.\left.\mathrm{VO}^{2+}\right), 2\right)$ chelated vanadium(IV) complexes and 3) complexes of vanadium(V) like mono- and diperoxovanadates $\left\{\left[\mathrm{VO}\left(\mathrm{O}_{2}\right)\left(\mathrm{H}_{2} \mathrm{O}\right)_{2}\left(\mathrm{~L}_{2}\right)\right]^{\mathrm{n}-}(\mathrm{n}=0,1)\right.$ and $\left(\left[\mathrm{VO}\left(\mathrm{O}_{2}\right)_{2}\left(\mathrm{~L}_{2}\right)\right]^{\mathrm{n}-}(\mathrm{n}=\right.$ 1,2,3), where $\mathrm{L}_{2}$ denote bidentate ligand\} [2]. The discovery of oxovanadates(V) and oxovanadium(IV) with the insulin-like in vivo and in vitro activity, as for example $\mathrm{VOSO}_{4}$, can have a promising use in the treatment of non-insulin-dependent type2 diabetes mellitus [3,4]. Certain vanadium complexes like as bis(maltolato)oxovanadium(IV), bis(ethylmaltolato)oxovanadium(IV) or bis(isopropylmaltolato)oxovanadium(IV) are found to be promising candidates as oral complements for insulin in the treatment of diabetes [5-8]. In comparison to $\mathrm{VOSO}_{4}$ the mentioned vanadium complexes have less toxicity, higher potency and better absorption in human digestive system [5]. The search for new vanadium complex compounds with decreased toxicity and increased potency still continues. The vanadium

*Corresponding author: szklarze@chemia.uj.edu.pl, tel: 48-12-686-2504, fax: 48-12-686-2750 complexes with Schiff base ligands have also become promising [9-11].

In this paper we described the synthesis and physicochemical characterization of new vanadium(V) complex with Schiff base ligand derived from 5-methoxysalicylaldehyde and phenylacetic hydrazide for which the determination of stability in solutions at pH 7.0 and 2.0, studied by UV-Vis spectroscopy, allowed to determine the possibility of using this compound as potential insulin-mimetic agent.

\section{Materials and Methods}

[VO (acac $\left.)_{2}\right]$, 5-methoxysalicylaldehyde and phenylacetic hydrazide, were of analytical grade (Aldrich) and were used as supplied. Ethanol (98\%) of pharmaceutical grade was from Polmos, all other solvents were of analytical grade and were used as supplied. $\mathrm{BaSO}_{4}$ was of spectroscopic grade (Japan). $\mathrm{Bu}_{4} \mathrm{NPF}_{6}$ was synthesized from $\mathrm{Bu}_{4} \mathrm{NBr}$ and $\mathrm{KPF}_{6}$ by a standard method [12] and recrystallized from acetone. Microanalysis of carbon, hydrogen and nitrogen were performed using Elementar Vario MICRO Cube elemental analyzer. IR spectrum was recorded on a Bruker EQUINOX 55 FT-IR spectrophotometer in $\mathrm{KBr}$ pellets. The electronic absorption spectra were recorded on Shimadzu UV-3600 UV-Vis-NIR spectrophotometer equipped with a CPS-240 temperature controller. Complex stability measurements in $\mathrm{DMSO} / \mathrm{H}_{2} \mathrm{O}(20 \mu \mathrm{l} / 3 \mathrm{ml})$ mixture were performed at $\mathrm{c}=5.0 \times 10^{-5} \mathrm{M}, \mathrm{pH}=7.00$ and at $\mathrm{pH}=2.00(0.1 \mathrm{M} \mathrm{KCl}, \mathrm{HCl}$ added to adjust the $\mathrm{pH}$ ). The spectra were measured every $340 \mathrm{~s}$ 
at $37^{\circ} \mathrm{C}$ on Shimadzu UV-3600 UV-Vis-NIR spectrophotometer in $1 \mathrm{~cm}$ UV cuvettes. The magnetic susceptibility measurement was performed on a SHERWOOD SCIENTIFIC magnetic susceptibility balance. The cyclic voltammetry measurements were carried out in DMSO with $\left[\mathrm{Bu}_{4} \mathrm{~N}\right] \mathrm{PF}_{6}(0.1 \mathrm{M})$ as the supporting electrolyte, using $\mathrm{Pt}$ working and counter and $\mathrm{Ag} / \mathrm{AgCl}$ as reference electrodes on an AUTOLAB/PGSTAT $128 \mathrm{~N}$ Potentiostat/ Galvanostat. $\mathrm{E}_{1 / 2}$ values were calculated from the average anodic and cathodic peak potentials, $\mathrm{E}_{1 / 2}=0.5\left(\mathrm{E}_{\mathrm{a}}+\mathrm{E}_{\mathrm{c}}\right)$. The redox potentials were calibrated versus ferrocene $(0.440 \mathrm{~V}$ versus $\mathrm{SHE})$, which was used as an internal potential standard for measurements in organic solvents to avoid the influence of a liquid junction potential; the final values are reported versus the standard hydrogen electrode (SHE). DTG measurements were performed on a TGA/SDTA 851e Mettler Toledo Microthermogavimeter under argon (in the $25-1000{ }^{\circ} \mathrm{C}$ range) and in air atmosphere (in the $25-750^{\circ} \mathrm{C}$ range) with scan speed $10^{\circ} \mathrm{C} / \mathrm{min}$.

\section{Synthesis}

In the one step reaction, the Schiff base ligand (L) was synthesized in situ from 5-methoxysalicylaldehyde and phenylacetic hydrazide in $1: 1$ molar ratio. Then, the vanadyl acetylacetonate was added under anaerobic conditions (Ar).

\section{[VO(L)(EtO)(EtOH)], 1}

The 5-methoxysalicylaldehyde $(0.187 \mathrm{ml}, 1.5 \mathrm{mmol})$ and the phenylacetic hydrazide $(0.225 \mathrm{~g}, 1.5 \mathrm{mmol})$ in $50 \mathrm{ml}$ of ethanol were refluxed for 11 minutes under Ar. Then the $\left[\mathrm{VO}(\mathrm{acac})_{2}\right]$ $(0.399 \mathrm{~g}, 1.5 \mathrm{mmol})$ was added. The reflux was continued for 58 minutes under Ar. The solution was evaporated in part but precipitation was observed next day in refrigerator. The obtained very dark green (almost black) compound was filtered off, washed with ethanol and dried in air. Yield: $0.410 \mathrm{~g}, 62 \%$. $\mathrm{MW}=440.36$. Anal. Calcd. for $\mathrm{C}_{20} \mathrm{H}_{25} \mathrm{~N}_{2} \mathrm{O}_{6} \mathrm{~V}: \mathrm{C}, 54.55 ; \mathrm{H}, 5.72$; $\mathrm{N}, 6.36 \%$. Found: C, 54.36; H, 5.64; N, $6.34 \%$. The complex is diamagnetic.

\section{Crystallographic data collection and structure refinement}

The crystal of 1 suitable for X-ray analysis was selected from the materials prepared as described in the Synthetic procedure. The crystal data, details of data collection and structure refinement parameters are summarized in Table 1. Intensity data for $\mathbf{1}$ was collected on a Super Nova diffractometer using monochromatic MoKa radiation, $\lambda=0.71073 \AA$. The structure was solved by direct methods [13] and the least-squares refinements were performed with the SHELXL-2014 program [14]. The positions of all atoms were determined by direct methods. All non-hydrogen atoms were refined anisotropically using weighted full-matrix least-squares on $\mathrm{F}^{2}$. Hydrogens were included in the structure at idealized positions. The figures were made using DIAMOND software [15]. Crystallographic data for the structural analysis have been deposited with the Cambridge Crystallographic Data Centre, CCDC No. 1871642.

\section{Results and Discussion}

The reaction of in situ formed Schiff base ligand based on 5-methoxysalicylaldehyde and phenylacetic hydrazide with $\left[\mathrm{VO}(\mathrm{acac})_{2}\right]$ in ethanolic solution, under anaerobic conditions, results in formation of green-black transparent solution. Cooling the solution enabled crystals to be obtained. The magnetic susceptibility measurement indicates on $\mathrm{V}(\mathrm{V})$ oxidation state for complex 1. The compound is stable in air and soluble in organic solvents, but almost insoluble in water.

\section{Crystal structure}

The complex 1 crystallizes in the triclinic space group P-1 with the asymmetric cell unit containing two molecules of [VO(L) $(\mathrm{EtO})(\mathrm{EtOH})]$ complex. The selected bond lengths and angles for $\mathbf{1}$ are listed in Table 2, whereas the molecular structure is presented in Fig. 1. The Schiff base ligand coordinates in a tridentate mode to afford a distorted octahedral geometry. In complex 1 the O7, N11 and O21 from the $\mathrm{L}_{\mathrm{ONO}}{ }^{2-}$ Schiff base ligand and oxygen atom (O22) of $\mathrm{EtO}^{-}$ligand are occupying equatorial, whereas oxido ligand $(\mathrm{O} 28)$ and oxygen atom $(\mathrm{O} 25)$ of $\mathrm{EtOH}$ ligand axial positions. The $\mathrm{V}=\mathrm{O}$ bond is the shortest $[1.5837(15)$ $\AA$ ], while V-O25 (from EtOH molecule) is the longest one, as expected for the trans effect [2.3824(17) $\AA$ ]. The vanadium atom is shifted of the square plane, occupied by ONO ligand and $\mathrm{EtO}^{-}$ molecule, by $0.304 \AA$. The phenolic ring is strongly bent, the angle between plane with salicylaldehyde and that with phenolic plane is $73.69^{\circ}$. The similar angle was observed in other com-

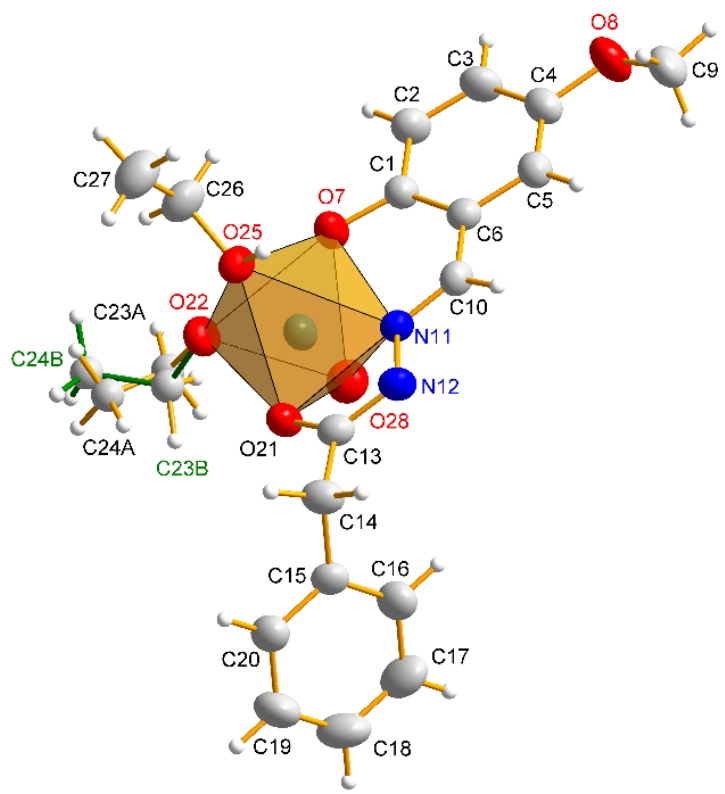

Figure 1. The molecular structure of complexes 1 together with the atom labelling scheme. All non-hydrogen atoms are represented at 30\% probability thermal ellipsoids 
Table 1. Crystal data and structure refinement for 1

\begin{tabular}{|c|c|}
\hline \multicolumn{2}{|c|}{1} \\
\hline Empirical formula & $\mathrm{C}_{20} \mathrm{H}_{25} \mathrm{~N}_{2} \mathrm{O}_{6} \mathrm{~V}$ \\
\hline Formula weight & 440.36 \\
\hline Crystal size (mm) & $0.630 \times 0.190 \times 0.100$ \\
\hline Crystal system & Triclinic \\
\hline Space group & $\mathrm{P}-1$ \\
\hline $\mathrm{a}(\AA)$ & $10.467(5)$ \\
\hline $\mathrm{b}(\AA)$ & $10.683(5)$ \\
\hline $\mathrm{c}(\AA)$ & $10.991(5)$ \\
\hline$\alpha\left(^{\circ}\right)$ & $118.752(5)$ \\
\hline$\beta\left(^{\circ}\right)$ & $94.900(5)$ \\
\hline$\gamma\left({ }^{\circ}\right)$ & $96.272(5)$ \\
\hline $\mathrm{h}$ & $-13 \leq \mathrm{h} \leq 13$ \\
\hline $\mathrm{k}$ & $-13 \leq \mathrm{k} \leq 13$ \\
\hline 1 & $-13 \leq 1 \leq 13$ \\
\hline $\mathrm{V}\left(\AA^{3}\right)$ & $1057.5(9)$ \\
\hline $\mathrm{Z}$ & 2 \\
\hline $\mathrm{T}(\mathrm{K})$ & 293(2) \\
\hline Wavelength $[\AA]$ & 0.71073 \\
\hline $\mathrm{D}_{\mathrm{x}}\left(\mathrm{mg} / \mathrm{m}^{3}\right)$ & 1.383 \\
\hline Absorption coefficient $\left(\mathrm{mm}^{-1}\right)$ & 0.507 \\
\hline $\mathrm{F}(000)$ & 460 \\
\hline Theta range for data collection $\left(^{\circ}\right)$ & 3.722 to 26.374 \\
\hline Reflections collected & 13522 \\
\hline Independent reflections & $4316[\mathrm{R}(\mathrm{int})=0.0224]$ \\
\hline Completeness to theta & $99.7 \%\left(25.242^{\circ}\right)$ \\
\hline Absorption correction & Semi-empirical from equivalents \\
\hline Refinement method & Full-matrix least-squares on $\mathrm{F}^{2}$ \\
\hline Data / restraints / parameters & $4316 / 24 / 289$ \\
\hline Goodness-of-fit on $\mathrm{F}^{2}$ & 1.082 \\
\hline Final $R$ indices $[\mathrm{I}>2 \operatorname{sigma}(\mathrm{I})]$ & $\mathrm{R} 1=0.0343, \mathrm{wR} 2=0.0942$ \\
\hline $\mathrm{R}$ indices (all data) & $\mathrm{R} 1=0.0456, \mathrm{wR} 2=0.0989$ \\
\hline Largest diff. peak and hole $\left(\mathrm{e} . \AA^{-3}\right)$ & 0.239 and -0.234 \\
\hline
\end{tabular}

plexes with similar diphenyl ligands as for example for square planar copper complex $-70.81^{\circ}$, for octahedral copper $-78.23^{\circ}$ [16], for silver complex $-85.38^{\circ}$ [17], for hexameric manganese complex $-68.80^{\circ}[18]$ and for trimeric Ni(II) complex - $80.84^{\circ}$ [19]. There are two coordination geometries of ONO ligand in $1: 1$ ratio present in the crystal, the planes containing two phenolic rings of two isomers are parallel to each other with the distance of $1.117 \AA$.

The molecular packing is presented in Fig. 2. Two adjacent complexes are connected by two hydrogen bonds between O25-N12, and O25'-N12' as shown in Fig. 3 and in Table 3. The bond distance is $2.825 \AA$, with the angle of $172^{\circ}$ indicating on relatively strong interactions. Second hydrogen bond between $\mathrm{O} 26$ and $\mathrm{O} 22$ is very weak, as the angle is only $111.9^{\circ}$. There are none $\pi-\pi$ interactions or any other strong intermolecular interactions which could keep the structure and which could form a net of intermolecular interactions. Between layers, shown in Fig. 2, there are only short contacts. All this indicates that the structure is simply a packing of separated hydrogen bonded dimers.
Table 2. Selected bond lengths $[\AA]$ and bond angles $\left[^{\circ}\right]$ in 1

\begin{tabular}{llll}
\hline bond lengths & \multicolumn{3}{l}{ bond angles } \\
\hline $\mathrm{V}(1)-\mathrm{O}(28)$ & $1.5837(15)$ & $\mathrm{O}(28)-\mathrm{V}(1)-\mathrm{O}(22)$ & $102.78(7)$ \\
$\mathrm{V}(1)-\mathrm{O}(22)$ & $1.7570(14)$ & $\mathrm{O}(28)-\mathrm{V}(1)-\mathrm{O}(7)$ & $100.42(8)$ \\
$\mathrm{V}(1)-\mathrm{O}(7)$ & $1.8488(14)$ & $\mathrm{O}(22)-\mathrm{V}(1)-\mathrm{O}(7)$ & $102.93(6)$ \\
$\mathrm{V}(1)-\mathrm{O}(21)$ & $1.9662(14)$ & $\mathrm{O}(28)-\mathrm{V}(1)-\mathrm{O}(21)$ & $96.91(7)$ \\
$\mathrm{V}(1)-\mathrm{N}(11)$ & $2.1278(16)$ & $\mathrm{O}(22)-\mathrm{V}(1)-\mathrm{O}(21)$ & $93.13(7)$ \\
$\mathrm{V}(1)-\mathrm{O}(25)$ & $2.3824(17)$ & $\mathrm{O}(7)-\mathrm{V}(1)-\mathrm{O}(21)$ & $153.02(6)$ \\
$\mathrm{C}(10)-\mathrm{N}(11)$ & $1.287(2)$ & $\mathrm{O}(28)-\mathrm{V}(1)-\mathrm{N}(11)$ & $95.06(6)$ \\
$\mathrm{N}(11)-\mathrm{N}(12)$ & $1.399(2)$ & $\mathrm{O}(22)-\mathrm{V}(1)-\mathrm{N}(11)$ & $159.33(7)$ \\
$\mathrm{N}(12)-\mathrm{C}(13)$ & $1.305(2)$ & $\mathrm{O}(7)-\mathrm{V}(1)-\mathrm{N}(11)$ & $83.74(6)$ \\
$\mathrm{C}(13)-\mathrm{O}(21)$ & $1.295(2)$ & $\mathrm{O}(21)-\mathrm{V}(1)-\mathrm{N}(11)$ & $74.23(6)$ \\
$\mathrm{O}(22)-\mathrm{C}(23 \mathrm{~B})$ & $1.423(4)$ & $\mathrm{O}(28)-\mathrm{V}(1)-\mathrm{O}(25)$ & $174.76(6)$ \\
$\mathrm{O}(22)-\mathrm{C}(23 \mathrm{~A})$ & $1.72(5)$ & $\mathrm{O}(22)-\mathrm{V}(1)-\mathrm{O}(25)$ & $81.05(6)$ \\
$\mathrm{O}(25)-\mathrm{C}(26)$ & $1.436(2)$ & $\mathrm{O}(7)-\mathrm{V}(1)-\mathrm{O}(25)$ & $82.03(6)$ \\
$\mathrm{O}(25)-\mathrm{H}(25)$ & $0.744(19)$ & $\mathrm{O}(21)-\mathrm{V}(1)-\mathrm{O}(25)$ & $79.19(6)$ \\
$\mathrm{C}(26)-\mathrm{C}(27)$ & $1.492(3)$ & $\mathrm{N}(11)-\mathrm{V}(1)-\mathrm{O}(25)$ & $80.54(5)$ \\
$\mathrm{C}(23 \mathrm{~A})-\mathrm{C}(24 \mathrm{~A})$ & $1.240(4)$ & $\mathrm{C}(1)-\mathrm{O}(7)-\mathrm{V}(1)$ & $134.01(11)$ \\
$\mathrm{C}(23 \mathrm{~B})-\mathrm{C}(24 \mathrm{~B})$ & $1.399(10)$ & $\mathrm{C}(10)-\mathrm{N}(11)-\mathrm{V}(1)$ & $127.57(12)$ \\
& & $\mathrm{N}(12)-\mathrm{N}(11)-\mathrm{V}(1)$ & $115.51(10)$ \\
& & $\mathrm{C}(13)-\mathrm{O}(21)-\mathrm{V}(1)$ & $118.41(11)$ \\
& & $\mathrm{C}(23 \mathrm{~B})-\mathrm{O}(22)-\mathrm{V}(1)$ & $129.9(3)$ \\
& & $\mathrm{C}(23 \mathrm{~A})-\mathrm{O}(22)-\mathrm{V}(1)$ & $128.5(12)$ \\
& & $\mathrm{C}(26)-\mathrm{O}(25)-\mathrm{V}(1)$ & $119.38(12)$ \\
& & $\mathrm{V}(1)-\mathrm{O}(25)-\mathrm{H}(25)$ & $116.6(16)$ \\
& & \\
& & & \\
& & & \\
& & & \\
& & & \\
& & & \\
& & &
\end{tabular}

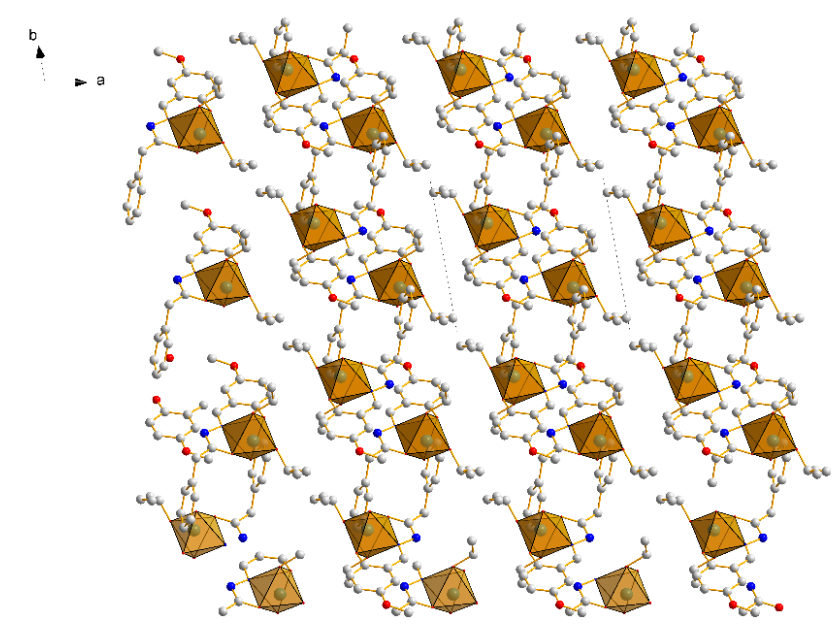

Figure 2. The crystal packing in 1 through [001] direction

Table 3. The hydrogen bonds for $1\left[\AA\right.$ and $\left.{ }^{\circ}\right]$

\begin{tabular}{lllll}
\hline $\mathrm{D}-\mathrm{H} \ldots \mathrm{A}$ & $\mathrm{d}(\mathrm{D}-\mathrm{H})$ & $\mathrm{d}(\mathrm{H} \ldots \mathrm{A})$ & $\mathrm{d}(\mathrm{D} \ldots \mathrm{A})$ & $<(\mathrm{DHA})$ \\
\hline $\mathrm{C}(26)-\mathrm{H}(26 \mathrm{~A}) \ldots \mathrm{O}(22)$ & 0.97 & 2.62 & $3.113(3)$ & 111.9 \\
$\mathrm{O}(25)-\mathrm{H}(25) \ldots \mathrm{N}(12) \# 1$ & $0.744(19)$ & $2.09(2)$ & $2.825(2)$ & $172(2)$ \\
\hline
\end{tabular}

Symmetry transformations used to generate equivalent atoms: \#1 - $\mathrm{x}+1,-\mathrm{y}+1,-\mathrm{z}+1$ 


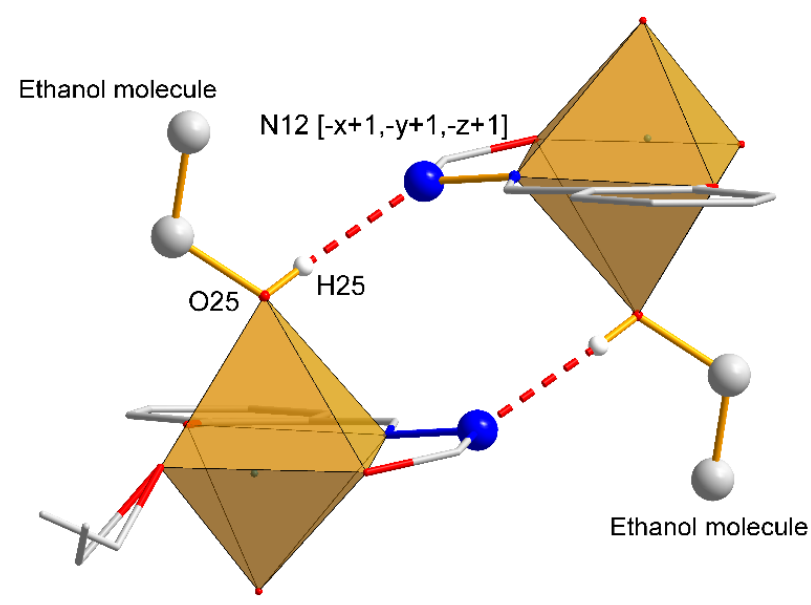

Figure 3. The hydrogen bonds in $\mathbf{1}$

\section{Spectral data}

The IR spectrum of complex $\mathbf{1}$ is presented in Fig. 4. In the 900 $-1000 \mathrm{~cm}^{-1}$ range, characteristic for $\mathrm{V}=\mathrm{O}$ vibration, two intensive bands at 918 and $978 \mathrm{~cm}^{-1}$ are observed, which indicates on the $V(V)$ oxidation state and it stays in line with magnetic susceptibility measurement. The band located at $1602 \mathrm{~cm}^{-1}$ can be assigned to $\mathrm{C}=\mathrm{N}$ group of Schiff base ligand. This band was also observed in the other oxidovanadium Schiff base complexes [20-22]. The lack of sharp band for $v_{\mathrm{OH}}$ group at ca. 3500 $\mathrm{cm}^{-1}$ indicates on involving of this group in coordination to the metal center and it stays in agreement with the crystal structure results. The sharp band at $2973 \mathrm{~cm}^{-1}$ can be assigned to EtOH ligand in complex $\mathbf{1}$.
The UV-Vis spectra were measured in water and in seven different organic solvents (Fig. 5). In the UV part of the electronic spectra the band attributed to the coordinated Schiff base ligand are observed as the separate peaks. In the visible part of the spectra, the band located at ca. $410 \mathrm{~nm}$, can be assigned to a LMCT (ligand-to-metal charge-transfer) transition between metal center and Schiff base ligand. This band is clearly visible for spectra measured in acetonitrile and DMF. The molar absorption coefficient in DMSO is $5.06 \cdot 10^{3} \mathrm{~mol}^{-1} \cdot \mathrm{cm}^{-1} \cdot \mathrm{dm}^{3}$ confirming its CT character. The lack of bands above $500 \mathrm{~nm}$ confirms $\mathrm{V}(\mathrm{V})$ oxidation state and $\mathrm{d}^{0}$ configuration.

The obtained complex is sparingly soluble in water and well soluble in DMF and DMSO. As, for biological activity, the solutions of the complex have to be delivered to in vitro and in vivo study, essential was to use aqueous solutions. Thus the concentrated solutions of $\mathbf{1}$ in DMSO were used and mixed with water prior to such a study. Therefore the stability of DMSO solutions of complex was studied as first and it was shown that in period of days DMSO solutions are stable in time. We did not use DMF, as DMSO is serviceable in for example medicine due to the fact that it supports the transfer of substances through biological membranes. The stability of the complex $\mathbf{1}$ was measured also in DMSO-water mixtures of composition used in biological tests. We used UV-Vis spectroscopy for stability investigations and DMSO- $\mathrm{H}_{2} \mathrm{O}$ mixture $(20 \mu \mathrm{l}+3 \mathrm{ml}$, respectively) at neutral $\mathrm{pH}$ and at $\mathrm{pH}=2.00$. This last $\mathrm{pH}$ was used, as oral administration of vanadium complexes results in its passing through stomach (were $\mathrm{pH}$ changes in range 1.5-2.5) and it is important that complex can be still stable in such conditions,

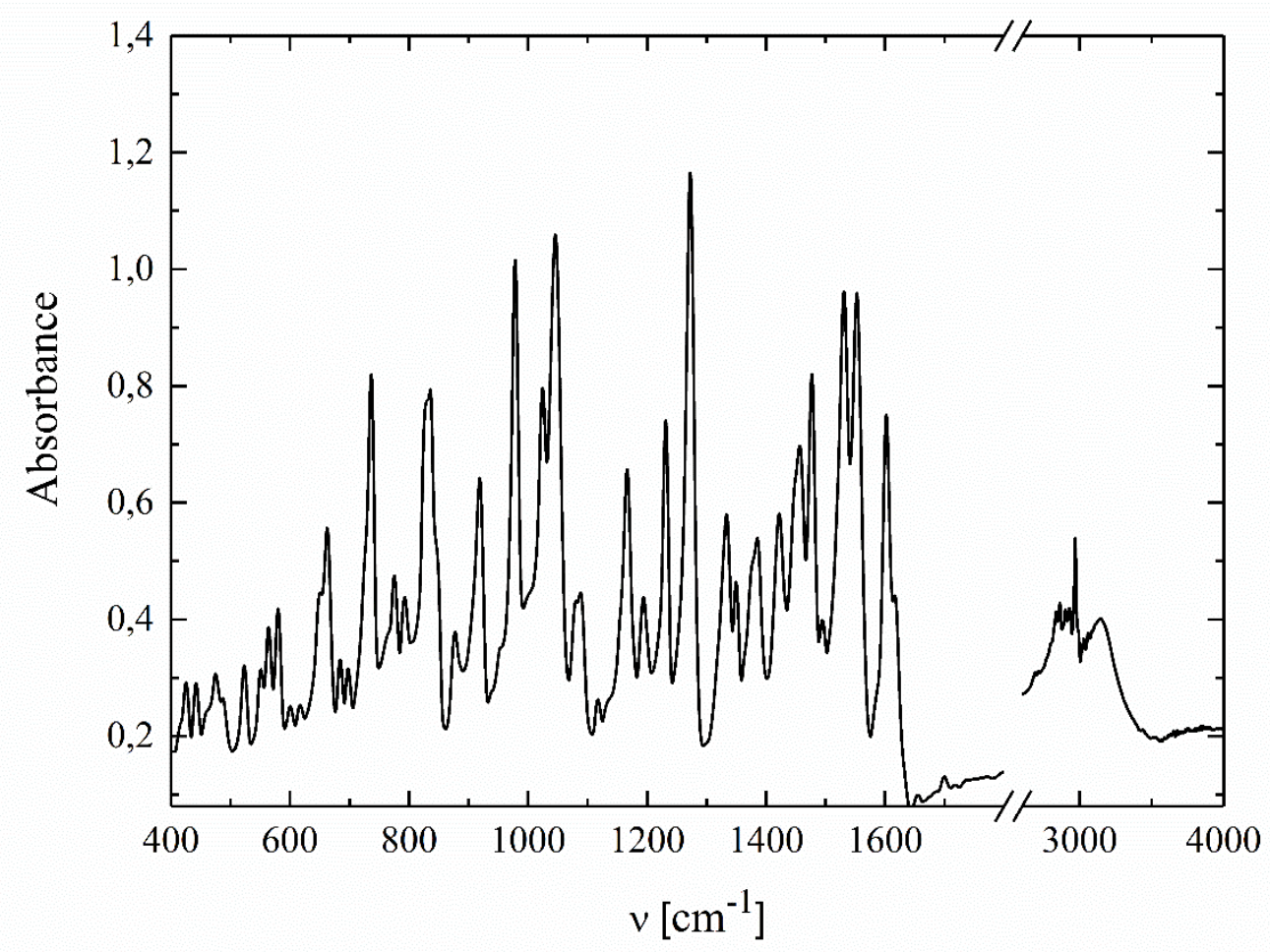

Figure 4. The IR spectrum of $\mathbf{1}$ in $\mathrm{KBr}$ 


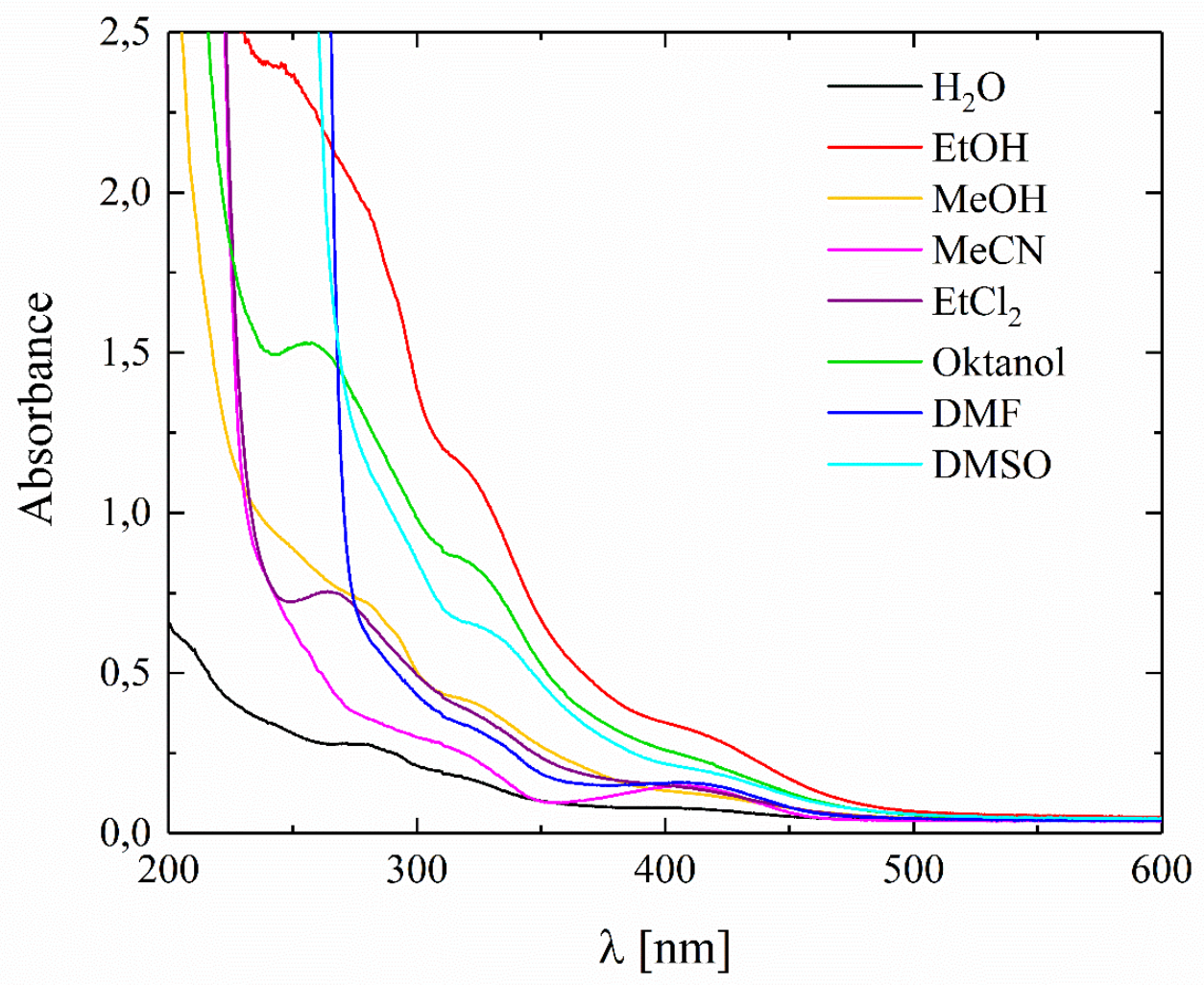

Figure 5. UV-Vis qualitative spectra of 1 in different solvents, $d=1 \mathrm{~cm}$

at least for some time. The UV-Vis spectra were measured over time for each $\mathrm{pH}$. The results of the measurements for $\mathrm{pH}=7.00$ are presented in Fig. 6 and for $\mathrm{pH}=2.00$ in Fig 7. The complex $\mathbf{1}$ is stable in neutral $\mathrm{pH}$, but it $\mathrm{pH}=2.00$ it gradually and very slowly decomposes. The decrease of CT band at ca. $400 \mathrm{~nm}$, indicates on ONO ligand release. The more complicated is the interpretation of the spectral change at $\mathrm{pH}=2.0$. Even for the first measured spectrum, no band at $c a .400 \mathrm{~nm}$ is observed. This indicates, that Schiff base was completely removed from the complex within ca. one minute prior to spectroscopic measurements. This situation was also observed for the other vanadium Schiff base complex [20].

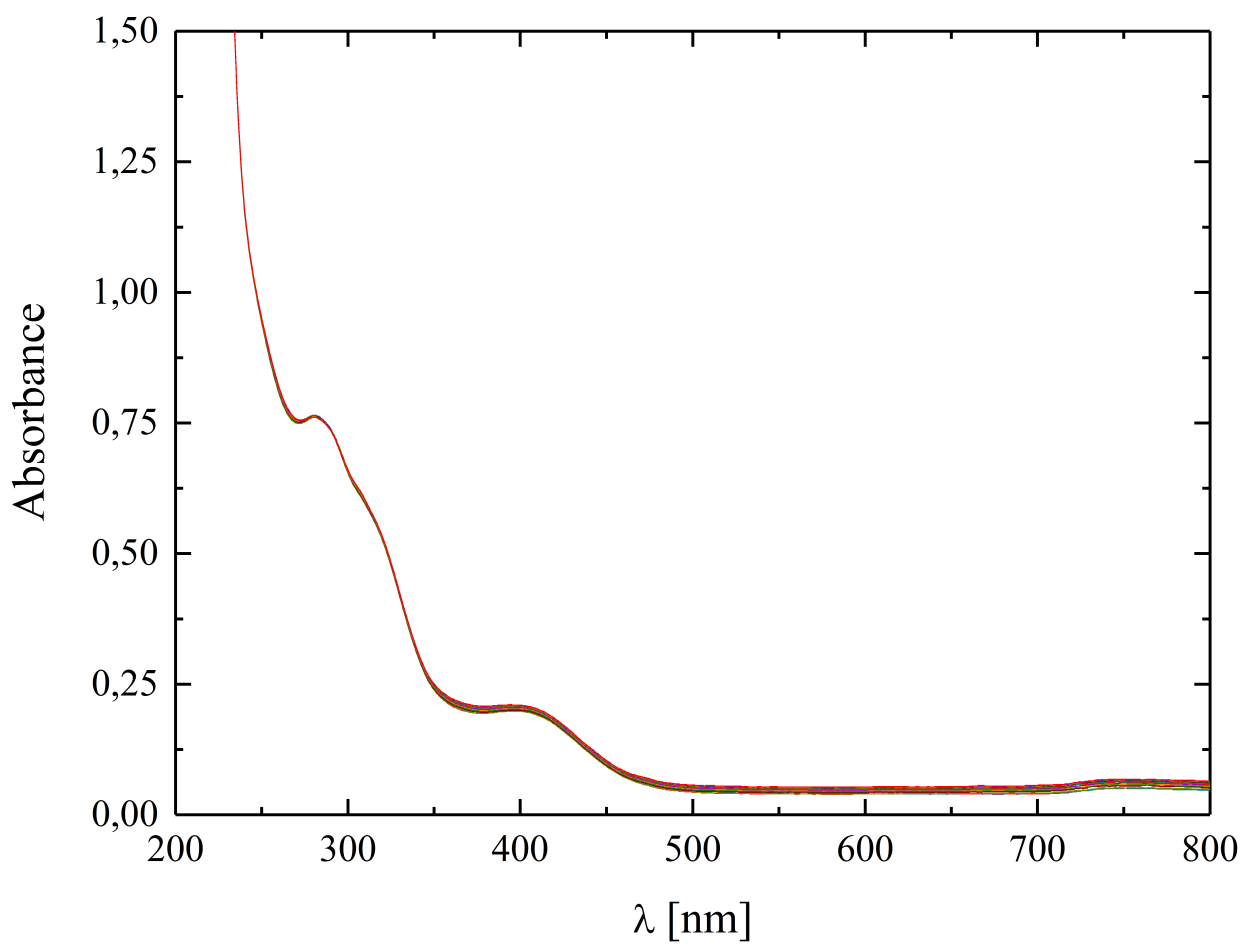

Figure 6. UV-Vis spectra of 1 in DMSO- $\mathrm{H}_{2} \mathrm{O}(20 \mu \mathrm{l}+3 \mathrm{ml})$ mixture at $\mathrm{pH}=7.00 . \mathrm{T}=37^{\circ} \mathrm{C}$, spectra measured in $340 \mathrm{~s}$ intervals 


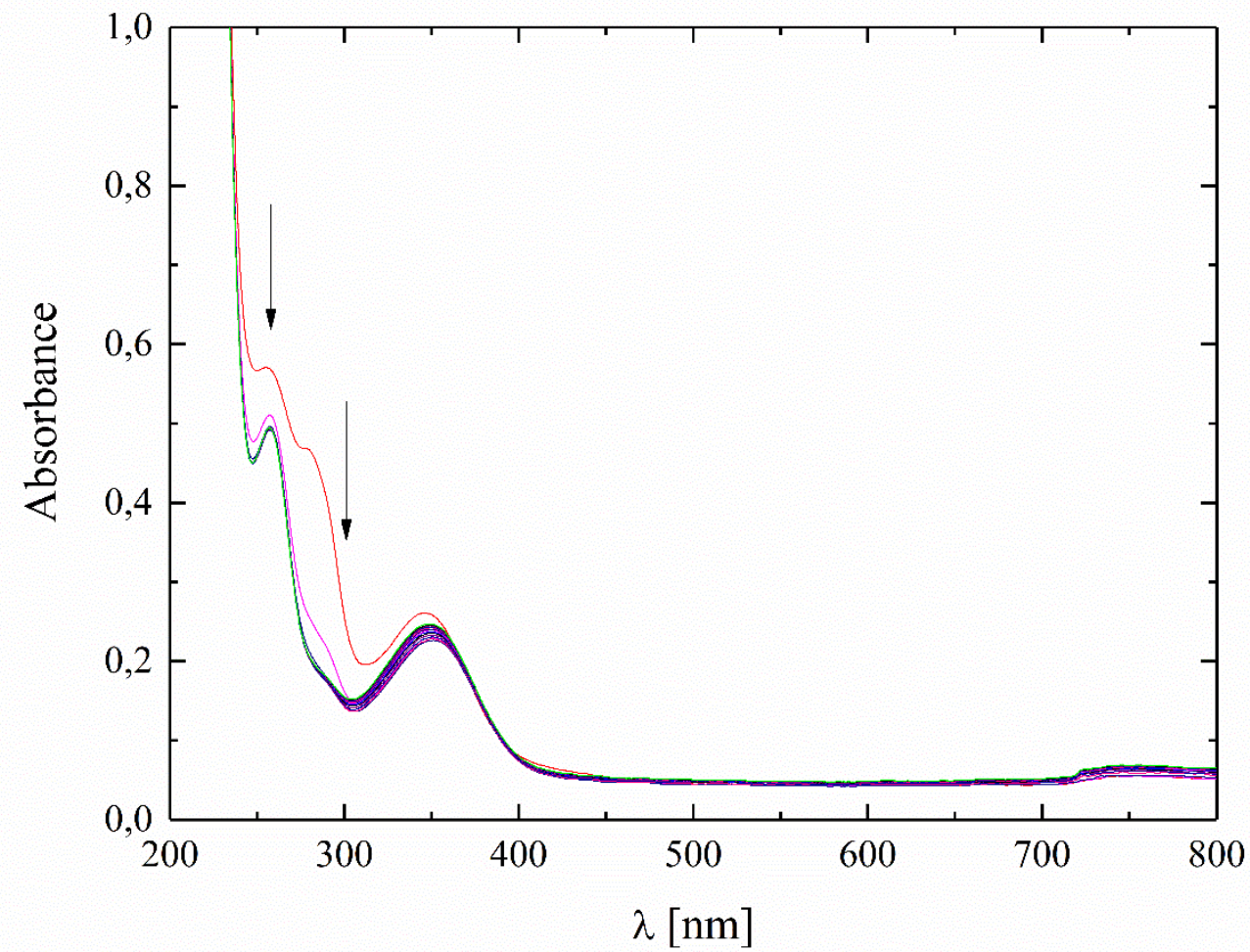

Figure 7. UV-Vis spectra of 1 in DMSO- $\mathrm{H}_{2} \mathrm{O}(20 \mu \mathrm{l}+3 \mathrm{ml})$ mixture at $\mathrm{pH}=2.00 . \mathrm{T}=37^{\circ} \mathrm{C}$, spectra measured in $340 \mathrm{~s}$ intervals. The arrows indicate the direction of the changes

\section{Cyclic voltammetry measurements}

The cyclic voltammetry for complex 1 was performed in DMSO (Fig. 8). On the voltammetric curve, one anode peak can be distinguished with extremely high potential $(0.430 \mathrm{~V})$, which can be attributed to irreversible oxidation to $V(V)$. Most likely, the oxidized form is so unstable that it is almost completely consumed as a result of subsequent reactions. The peak position is independent on scan speed, as shown in inset of the Fig. 8. What is more, in the return scan, appear the secondary three cathode peaks (at $0.162,-0.291$ and $-0.708 \mathrm{~V}$ ), corresponding to the processes of reduction of unstable anode reaction products.

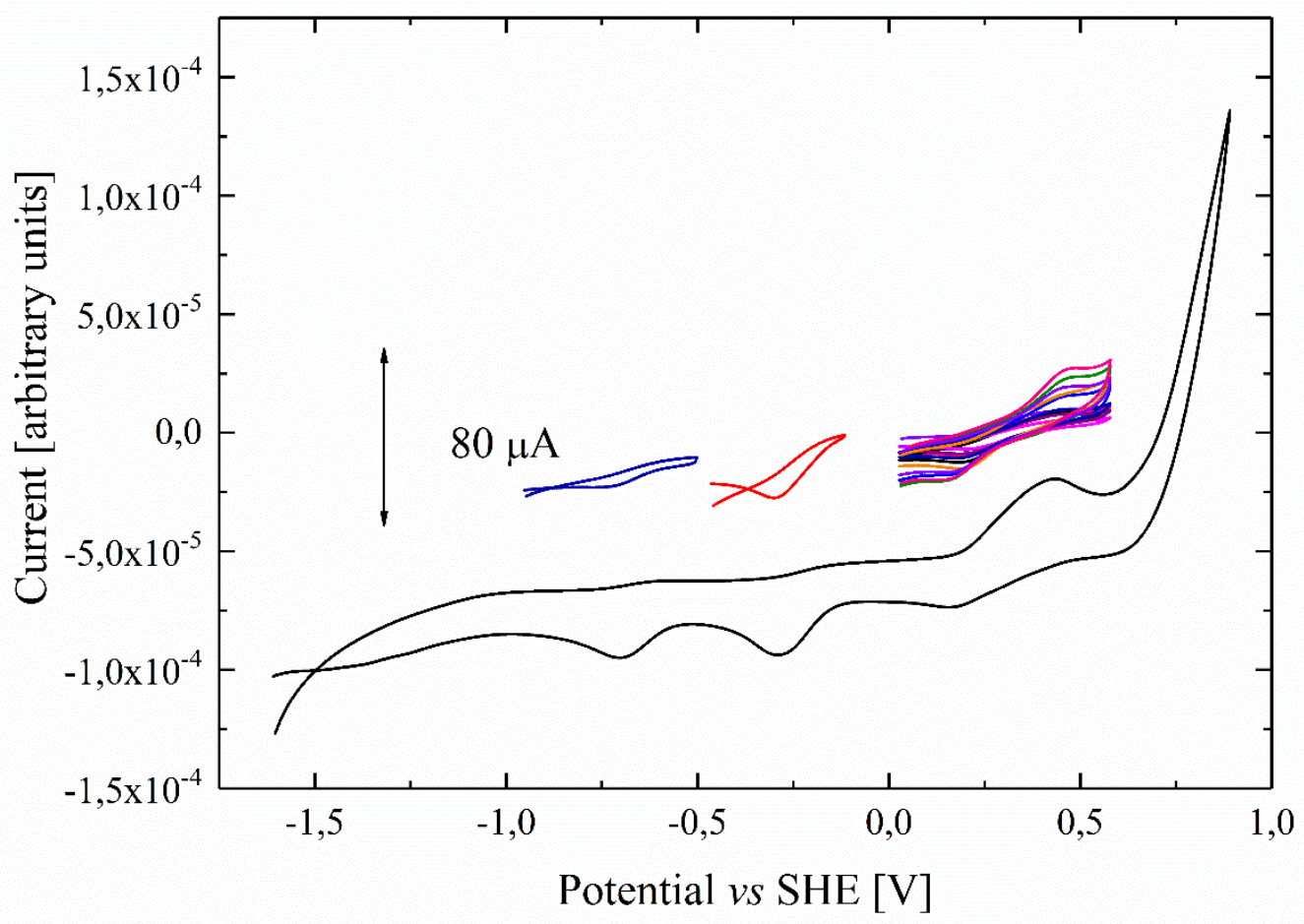

Figure 8. The cyclic voltammetry measurements of 1 in DMSO. Pt working and counting, $\mathrm{Ag} / \mathrm{AgCl}$ as a reference electrode, $0.1 \mathrm{M} \mathrm{Bu}_{4} \mathrm{NPF}_{6}$ as electrolyte. Scan speed $100 \mathrm{mV} \cdot \mathrm{s}^{-1}$. Insets, scan speed $100 \mathrm{mV} \cdot \mathrm{s}^{-1}$, for measurements at different scan speeds it vary from 20 to $250 \mathrm{mV} \mathrm{s}^{-1}$ 


\section{Thermogravimetry measurements}

TG and SDTA measurements were performed in air or under argon with a heating rate $10 \% \mathrm{~min}$ and are presented in Fig. 9 and Fig. 10 respectively. The numerical data are collected in Table 4.
$\mathrm{L}$ release. This last process is the most egzothermic one with SDTA $\mathrm{T}_{\max }$ at $524^{\circ} \mathrm{C}$. The ligand $\mathrm{L}$ is decomposed in two not resolved steps, indicating that it decomposes probably into initial aldehyde and hydrazide parts which are released in two distinct processes.

Table 4. TG and SDTA data for complex 1. Heating rate $10 \% \mathrm{~min}$

\begin{tabular}{|c|c|c|c|c|c|c|}
\hline Conditions & $\mathrm{M}[\mathrm{mg}]$ & $\begin{array}{c}\text { SDTA } \\
\mathrm{T}_{\max }\left[{ }^{\circ} \mathrm{C}\right]\end{array}$ & process & $\begin{array}{c}\Delta \mathrm{m}_{\exp } \\
{[\%]}\end{array}$ & $\begin{array}{c}\Delta \mathrm{m}_{\text {calc }} \\
{[\%]}\end{array}$ & Release of \\
\hline \multirow[t]{5}{*}{ In air } & 8.94001 & 73.8 & endo & & & \\
\hline & 8.0935 & 158 & egzo & 9.47 & 10.4 & $\mathrm{EtOH}$ \\
\hline & 7.41445 & 524 & egzo & 17.1 & 20.8 & $\mathrm{EtOH}$ \\
\hline & 6.33795 & & & 29.1 & & \\
\hline & 1.85378 & & & 79.3 & 85.0 & $\mathrm{~L}+2 \mathrm{EtOH}$ \\
\hline \multirow[t]{7}{*}{ Argon } & 5.71728 & 69 & endo & & & \\
\hline & 5.15267 & 167 & endo & 9.88 & 10.4 & $\mathrm{EtOH}$ \\
\hline & 4.70634 & 315 & endo & 17.7 & & \\
\hline & 2.88585 & 362 & endo & 49.5 & 45 & EtOH + aldehyde \\
\hline & 1.49052 & 451 & endo & 73.9 & 74.6 & $\mathrm{~L}+\mathrm{EtOH}$ \\
\hline & & 672 & endo & & & \\
\hline & & 848 & endo & & & \\
\hline
\end{tabular}

The first process, observed for both experiments below 100 ${ }^{\circ} \mathrm{C}$, is connected with the release of $\mathrm{EtOH}$ molecule in endothermic reaction. The lack of intermolecular hydrogen bonds, shown by X-ray measurements, and very weak intermolecular interaction allows the EtOH molecules to be released at relatively low temperature. There are two separated steps for EtOH release, at lower temperature coordinated neutral ethanol is released, while at higher one, second molecule of coordinated $\mathrm{EtO}^{-}$is released. The second step in air is connected not only with the second EtOH molecule release, but this process overlaps with the ligand
Under Ar, all decomposition processes are endothermic. After one $\mathrm{EtOH}$ molecule release (as in air) the decomposition processes overlaps yielding not so well defined plateaus on TG curve and stepwise mass loose up to $1000^{\circ} \mathrm{C}$ is observed. But even at this temperature no plateau on TG curve is observed. The final mass loose corresponds well with $\mathrm{L}$ and $\mathrm{EtOH}$ molecule release, but probably the scheme of complex decomposition is similar as in air, but due to the lack of oxygen, the vanadium carbides are formed at the end of the reaction decreasing the observed mass loose so much that part of the carbons from ligand $\mathrm{L}$ remains.

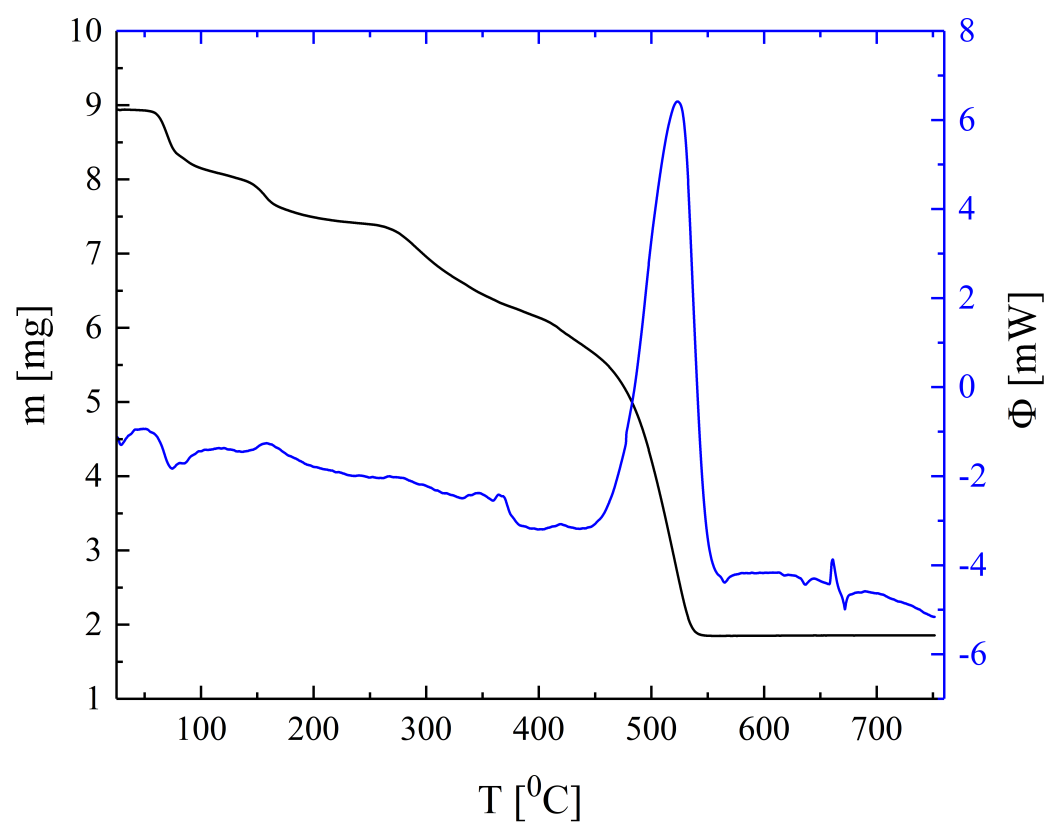

Figure 9. TG and SDTA curves of $\mathbf{1}$ in air. Scan rate $10 \% \mathrm{~min}$, air. The blue line represents the first derivative of TG curve 


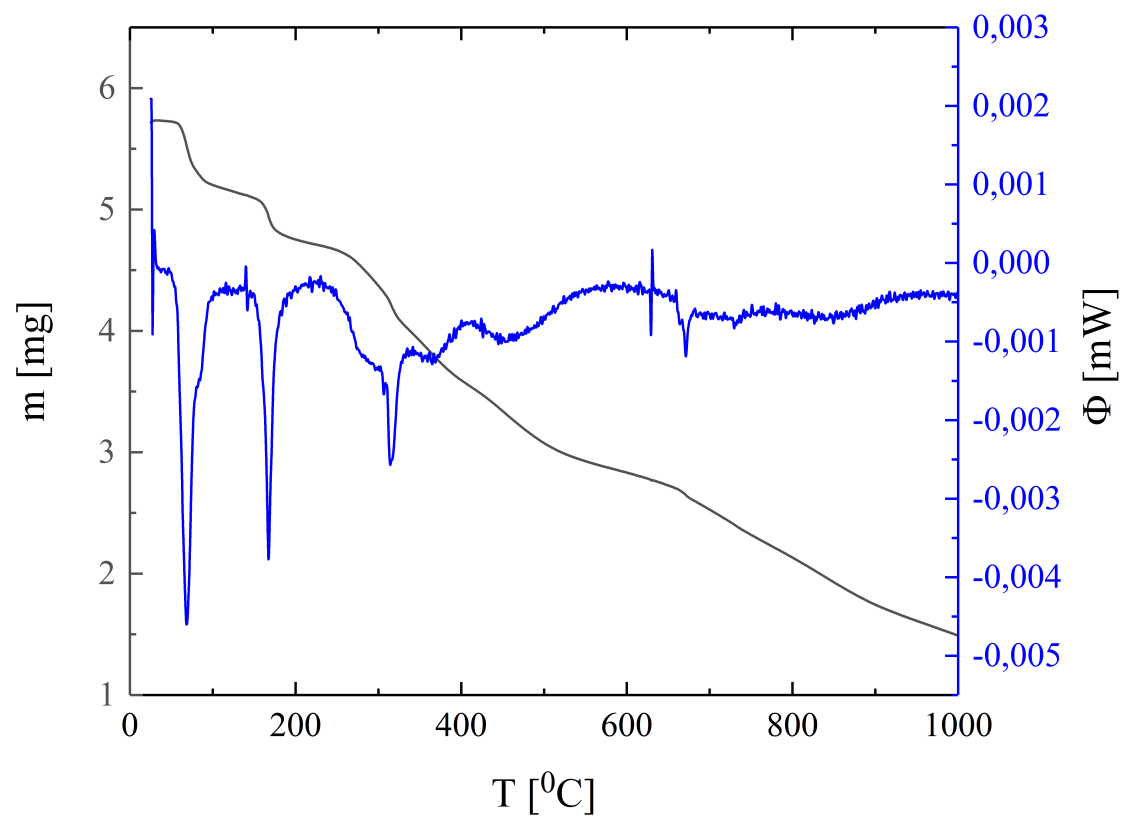

Figure 10. TG and SDTA curves of 1 under Ar. Scan rate $10 \%$ min, air. The blue line represent the first derivative of TG curve

\section{Conclusions}

The reaction of Schiff base components (5-methoxysalicylaldehyde and phenylacetic hydrazide) with $\left[\mathrm{VO}(\mathrm{acac})_{2}\right]$ results in isolation of $[\mathrm{VO}(\mathrm{L})(\mathrm{EtO})(\mathrm{EtOH})]$, where $\mathrm{L}=\mathrm{ONO}$ Schiff base ligand. The complex was structurally and spectroscopically characterized. The vanadium complexes with tridentate Schiff base ligand compared to bidentate complexes as for example bis(maltolato)oxovanadium(IV) (BMOV) seem to be more stable, thus they can probably be transferred to biological systems in unchanged form. Complex 1, in water-DMSO mixture, gradually and very slowly decomposes, but it seems that most of the complex can survive in digestion systems, and this creates the possibility of using it as an insulin mimetic compound.

\section{Acknowledgments}

This work was partly financed by the European Regional Development Fund under the Innovative Economy Programme 2007-2013 (WND POIG.01.03.01-174/09). The complexes are protected by the patent P.401493. We would like to thank dr Wojciech Przybylski for participation in synthesis.

\section{References}

1. Djordjevic C, Puryear PC, Vuletic N, Allelt CJ, Sheffield SJ. Preparation, spectroscopic properties, and characterization of novel peroxo complexes of vanadium( $\mathrm{V})$ and molybdenu$\mathrm{m}(\mathrm{VI})$ with nicotinic acid and nicotinic acid $\mathrm{N}$-oxide. Inorganic Chemistry. 1988;27:2926-2932.
2. Thompson KH, McNeill JH, Orvig C. In Topics in Biological Inorganic Chemistry; Clarke MJ, Sadler PJ, Eds. Springer-Verlag: Heidelberg, 1999, Vol. 2, p 139.

3. Nakai M, Watanabe H, Fujiwara C, Kakegawa H, Satoh T, Takada J, Matsushita R, Sakurai H. (1995). Mechanism on insulin-like action of vanadyl sulfate: studies on interaction between rat adipocytes and vanadium compounds. Biological and Pharmaceutical Bulletin. 1995;18:719-725.

4. Cusi K, Cukier S, DeFronzo RA, Torres M, Puchulu FM, Redondo JP. Vanadyl sulfate improves hepatic and muscle insulin sensitivity in type 2 diabetes. The Journal of Clinical Endocrinology \& Metabolism. 2001;86:1410-1417.

5. Thompson KH, Liboiron BD, Sun Y, Bellman KD, Setyawati IA, Patrick BO, Karunaratne V, Rawji G, Wheeler J, Sutton K, Bhanot S, Cassidy C, McNeill JH, Yuen VG, Bhanot S. Preparation and characterization of vanadyl complexes with bidentate maltol-type ligands; in vivo comparisons of anti-diabetic therapeutic potential. JBIC Journal of Biological Inorganic Chemistry. 2003;8:66-74.

6. Orvig C, Caravan P, Gelmini L, Glover N, Herring FG, Li H, McNeill JH, Rettig SJ, Setyawati IA. Reaction chemistry of BMOV, bis (maltolato) oxovanadium (IV), a potent insulin mimetic agent. Journal of the American Chemical Society. 1995; 117:12759-12770

7. Peters KG, Davis MG, Howard BW, Pokross M, Rastogi V, Diven C, Greis KD, Eby-Wilkens E, Maier M, Evdokimov A, Soper S, Soper S. Mechanism of insulin sensitization by BMOV (bis maltolato oxo vanadium); unliganded vanadium (VO4) as the active component. Journal of Inorganic Biochemistry. 2003;96:321-330. 
8. Wang J, Yuen VG, McNeill JH. Effect of vanadium on insulin and leptin in Zucker diabetic fatty rats. Molecular and Cellular Biochemistry. 2001;218:93-96.

9. Nejo AA, Kolawole GA, Opoku AR, Wolowska J, O’Brien P. Synthesis, characterization and preliminary insulin-enhancing studies of symmetrical tetradentate Schiff base complexes of oxovanadium (IV). Inorganica Chimica Acta. 2009;362:3993-4001.

10. Yuan C, Lu L, Gao X, Wu Y, Guo M, Li Y, Fu X, Zhu M. Ternary oxovanadium (IV) complexes of ONO-donor Schiff base and polypyridyl derivatives as protein tyrosine phosphatase inhibitors: synthesis, characterization, and biological activities. JBIC Journal of Biological Inorganic Chemistry. 2009; 14:841-851.

11. Meng XF, Liu QF, Liu JL, Sun MH, Ma JJ. Synthesis, crystal structure, and insulin-like activity of [N'-(2-hydroxy3-methoxybenzylidene)-2-methoxybenzohydrazonato] (1,10-phenanthroline) oxovanadium (IV) methanol solvate. Inorganic and Nano-Metal Chemistry. 2017;47:1585-1589.

12. Dümmling S, Eichhorn E, Schneider S, Speiser B, Würde M. Recycling of the Supporting Electrolyte Tetra(n-butyl)ammonium Hexafluorophosphate from Used Electrolyte Solutions. Current Separations. 1996;5:53-56.

13. Sheldrick GM. A short history of SHELX. Acta Crystallogr. Sect. A. 2008;64:112-122.

14. Sheldrick GM. SHELXL-2014. Program for Crystal Structure Solution. University of Göttingen, Germany. 2008.

15. Brandenburg K, Putz H. DIAMOND. Crystal Impact GbR, Bonn, Germany; 2015.

16. Repich HH, Orysyk SI, Orysyk VV, Zborovskii YL, Melnyk AK, Trachevskyi VV, Pekhnyo VI, Vovk MV. Influence of synthesis conditions on complexation of $\mathrm{Cu}$ (II) with
$\mathrm{O}, \mathrm{N}, \mathrm{O}$ tridentate hydrazone ligand. X-ray diffraction and spectroscopic investigations. Journal of Molecular Structure. 2017;1146:222-232.

17. Repich HH, Orysyk SI, Orysyk VV, Zborovskii YL, Pekhnyo VI, Vovk MV. Synthesis, crystal structure and spectral characterization of the first $\mathrm{Ag}^{+}$complex compounds involving O,N,O-coordinated N-acylhydrazones of salicylaldehyde. Journal of Molecular Structure. 2017;1144:225-236.

18. Luo W, Wang XT, Meng X-G, Cheng G-Z, Ji Z-P. Metal coordination architectures of $\mathrm{N}$-acyl-salicylhydrazides: The effect of metal ions and steric repulsion of ligands to their structures of polynuclear metal complexes. Polyhedron. 2009;28:300306.

19. Luo W, Meng X-G, Xiang J-F, Duan Y, Cheng G-Z, Ji Z-P. Synthesis, characterization and bioactivity of four novel trinuclear copper(II) and nickel(II) complexes with pentadentate ligands derived from $\mathrm{N}$-acylsalicylhydrazide. Inorganica Chimica Acta. 2008;361:2667-2676.

20. Gryboś R, Szklarzewicz J, Jurowska A, Hodorowicz M. Properties, structure and stability of V(IV) hydrazide Schiff base ligand complex. Journal of Molecular Structure. 2018;1171:880-887.

21. Ebrahimipour SY, Mohamadi M, Sheikhshoaie I, Suárez S, Baggio R, Khaleghi M. A novel oxido-vanadium (V) Schiff base complex: synthesis, spectral characterization, crystal structure, electrochemical evaluation, and biological activity. Research on Chemical Intermediates 2016;42:611-623.

22. Ebrahimipour SY, Abaszadeh M, Castro J, Seifi M. Synthesis, X-ray crystal structure, DFT calculation and catalytic activity of two new oxido-vanadium (V) complexes containing ONO tridentate Schiff bases. Polyhedron 2014;79:138-150. 